\title{
The health locus of control and health behaviours declared by students of health sciences
}

\section{Alina Deluga' , Paulina Bogdańska², Beata Dobrowolska³ , Barbara Ślusarska', Agnieszka Bartoszek , Katarzyna Szczekala ${ }^{4}$}

'Zakład Medycyny Rodzinnej i Pielęgniarstwa Środowiskowego, Wydział Nauk o Zdrowiu, Uniwersytet Medyczny w Lublinie 2Wojewódzki Ośrodek Medycyny Pracy, Nałęczowska 27, Lublin ${ }^{3}$ Katedra Rozwoju Pielęgniarstwa, Wydział Nauk o Zdrowiu, Uniwersytet Medyczny w Lublinie 4Studium Praktycznej Nauki Języków Obcych, Wydział Nauk o Zdrowiu Lublin, Uniwersytet Medyczny w Lublinie

\author{
CORRESPONDING AUTHOR/AUTOR DO KORESPONDENCJ: \\ Alina Deluga \\ Zakład Medycyny Rodzinnej i Pielęgniarstwa Środowiskowego \\ WNoZ UM w Lublinie \\ ul. Staszica 4-6. pok. 216, 20-081 Lublin \\ e-mail: alina_deluga@poczta.onet.pl
} Wstęp. Znaczącą rolę w podejmowaniu zachowań zdrowotnych przez poszczególne jednostki w tym ludzi młodych, odgrywa umiejscowienie kontroli zdrowia, które stanowi istotny czynnik wpływający na styl życia.

Cel pracy. Określenie wybranych uwarunkowań kontroli zdrowia i zachowań zdrowotnych studentów nauk o zdrowiu.

Materiał i metodyka. Badaniami objęto grupę 175 studentów nauk o zdrowiu Uniwersytetu Medycznego w Lublinie. Użyto Wielowymiarowej Skali Umiejscowienia Kontroli Zdrowia (MHLC), wersja B, wg. Z. Juczyńskiego, która bada oczekiwania w trzech wymiarach kontroli zdrowia: wewnętrznym, wpływu innych oraz przypadku. Do oceny zachowań zdrowotnych wykorzystano autorski kwestionariusz ankiety.

Wyniki. Wyniki badań wskazują, że największy wpływ na zdrowie w badanej grupie studentów ma wewnętrzny wymiar kontroli zdrowia (25,86 pkt.). Badani z najstarszej grupy wiekowej oraz zamieszkujący tereny wiejskie przypisują temu wymiarowi wyższą rangę niż ankietowani z pozostałych grup. Studenci z zachowań zdrowotnych związanych z dbaniem o zdrowie najczęściej wymieniają zapinanie pasów bezpieczeństwa, zdrowe odżywianie i uprawianie sportu.

Wnioski. Wewnętrzny wymiar kontroli zdrowia jest istotnym czynnikiem determinującym zachowania zdrowotne badanych. Studenci, którzy nie potrafią ocenić czy są osobami zdrowymi, istotnie częściej przypisują największe znaczenie wpływowi innych na swoje zdrowie.

Słowa kluczowe: umiejscowienie kontroli zdrowia, zachowania zdrowotne, studenci by individuals including young ones.

Aim. The aim of the study was the determination of selected conditions of health control and health behaviours in students of health sciences.

Material and methods. The study encompassed 175 students of health sciences at the Medical University of Lublin. The multidimensional health locus of control scale (MHLC), version B, by Z. Juczyński was applied as it measures expectations in three dimensions of health control: internal, external (influence of others) and chance. A special authors' questionnaire compiled for the purpose was used to assess health behaviours.

Results. The results of the study show that the internal dimension of health control (25.86 points) has the greatest impact on health in the group studied. The oldest study participants dwelling in the countryside gave this dimension a higher ranking than other study participants. For the students health behaviours included fastening seat belts, healthy nutrition and doing sports.

Conclusions. The internal dimension of health control constitutes an essential factor determining health behaviours of the study participants. The students who are not able to assess whether they are healthy individuals, significantly more frequently perceive the greatest influence of others on their health. 


\section{INTRODUCTION}

Health is a value that lets individuals fulfil their aspirations and the need for satisfaction, as well as change their environment [1]. Health is usually acknowledged to be a preliminary condition of meeting life needs and a necessary medium of achieving different life aims. The most important factors conditioning health include health behaviours that make up lifestyle [2,3]. Health behaviours can be defined, in the light of modern medicine, as behaviours that trigger positive or negative effects in individuals who practise them [4]. Health behaviours are also determined as all behaviours including habits, customs, attitudes and values referring to health [5]. Behaviours favourable to health maintenance comprise, among others, regular physical activity, appropriate diet, sufficient sleep, avoidance of harmful substances, ways of coping with stress and fastening seat belts [6]. Health behaviours are shaped from early childhood due to numerous factors at home or school or in one's peer group. They constitute a component of lifestyle that is a characteristic way of behaving for an individual or group [7]. Lifestyle is a product of culture which is inextricably linked with it because culture creates lifestyle. Lifestyle accounts for roughly $60 \%$ of health potential [8].

The time when one is a student is unrepeatable in the life of young people. During that time, they try things out, make attempts and decisions on their lifestyle on their own. Students' lifestyles depend on many determinants like timetable, tiredness, distance between university and place of residence and different habits acquired at family home [9]. Therefore, health locus of control plays a significant role in choosing health behaviours in individual, even young people. The sense of control over health is characterised by conviction that one has an influence on his or her health [3].

\section{AIM}

The aim of the work was to separate selected determinants of health control and health behaviours in students of health sciences.

\section{MATERIALS AND METHODS}

The research was conducted in April and May 2016 among students of six different courses of studies (nursing, midwifery, paramedics, physiotherapy, dietetics and public health) at the Faculty of Health Sciences at the Medical University of Lublin. A total of 250 questionnaires were given and out of them 175 appropriately completed were collected (70\% of the response rate). No questionnaires were returned from students of Physiotherapy, Dietetics and Public Health.

A questionnaire specially compiled for this purpose was applied along with a standardised tool - the Multidimensional Health Locus of Control Scale version B (MHLC-B) by Z. Juczyński. The MHLC - B consists of 18 items regarding three dimensions of health control. The first dimension - internal (I) refers to control over health that depends on individuals on their own. The second dimension concerns the powerful influence (P) of others (including healthcare professional) on health. The third dimension regards chance (C) or an impact of other external factors on individuals' health. Reliability of the version B was 0.64 of the Cronbach's alpha coefficient for internal control, 0.63 for chance and 0.59 for the influence of others. The scale encompasses 6 degrees of assessment of particular items from 'I absolutely don't agree' (1) to 'I absolutely agree'(6) [10].

The authors' questionnaire was used to collect demographical data such as age, gender, place of residence, studies, questions of pro-health and anti-health behaviours.

The study was carried out consistently with the Declaration of Helsinki rules. Each respondent was informed of the aim of the study, assured of complete anonymity in the course of the research process and of the data obtained as well as of the possibility to resign from the study participation. Values of the parameters analysed were characterised by number, percentage, mean and median values. For continuous variables, the Mann-Whitney U test used to assess differences between the two groups and the Kruskal-Wallis test was applied for several groups. Statistical analyses were conducted using computer software SPSS Statistics 12.0.

\section{Characteristics of the study group}

The questionnaire was appropriately completed by 175 (70\%) students of the following three courses: nursing - $81(46.3 \%)$, midwifery $-72(41.1 \%)$ and paramedics $22(12.6 \%)$. Females constituted $85.7 \%(n=150)$, males $14.3 \%(n=25)$. The average age of the respondents was 21.4 years old $(\mathrm{SD}=3.6)$. The youngest respondent was 19 years old while the oldest one was 49 . Half of the respondents $(50.9 \%)$ was from 19 to 20 years old, $24 \%$ of students was 21 years old and $25.1 \%$ was 22 years or older. Over $56.6 \%$ of the students came from the rural areas and the remaining ones $43.4 \%$ from the urban areas. More than $54.3 \%$ of the respondents lived in lodgings, a third (33.1\%) in a family house and $12.6 \%$ in the dormitory.

\section{RESULTS}

The study participants attributed significance to internal health control as a factor affecting health to the greatest extent (Fig. 1.).

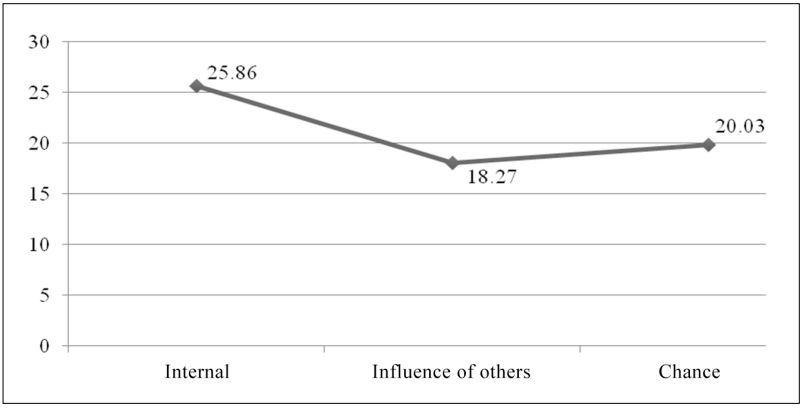

Fig 1. Dimensions of health locus of control according to the students researched. 
In the dimension of internal health control, the study participants most frequently indicated the following items: "I am fully responsible for my health" (5.24 points), "My physical well-being depends on how well I take care of myself" ( 4.75 points) and "When I become ill, I recover on my own' (4.50 points). Tab.1.

Tab. 1. Dimension of internal health control according to the students.

\begin{tabular}{|l|c|c|c|c|}
\hline \multicolumn{1}{|c|}{ Internal control } & Min. & Max. & Mean & $\begin{array}{c}\text { Standard } \\
\text { Deviation }\end{array}$ \\
\hline $\begin{array}{l}\text { When I become ill, I recover } \\
\text { on my own }\end{array}$ & 1.00 & 6.00 & 4.5029 & 1.21709 \\
\hline $\begin{array}{l}\text { I am fully responsible } \\
\text { for my health }\end{array}$ & 2.00 & 6.00 & 5.2428 & 1.94562 \\
\hline $\begin{array}{l}\text { Whatever bad happens } \\
\text { with my health, it is my fault }\end{array}$ & 1.00 & 6.00 & 3.1829 & 1.43067 \\
\hline $\begin{array}{l}\text { My physical well-being depends } \\
\text { on how well I take care of myself }\end{array}$ & 1.00 & 6.00 & 4.7529 & 1.13375 \\
\hline $\begin{array}{l}\text { When I am ill, I know that it is } \\
\text { a result of lack of taking care of } \\
\text { myself }\end{array}$ & 1.00 & 6.00 & 3.7701 & 1.34036 \\
\hline When I am ill, it is my fate & 1.00 & 6.00 & 4.4128 & 1.16401 \\
\hline
\end{tabular}

In the dimension of the influence of others, the students chose the items as follows: "The care I get from others determines how speedy my recovery is"(3.73 points), "Exact following of doctor's instructions is the best way of maintaining good health" (3.41 points), and "If I regularly consult a good doctor, I will lower the probability of becoming ill” (3.13 points). Tab. 2 .

Tab. 2. Dimension of the influence of others according to the students.

\begin{tabular}{|c|c|c|c|c|}
\hline Influence of others & Min. & Max. & Mean & $\begin{array}{l}\text { Standard } \\
\text { Deviation }\end{array}$ \\
\hline $\begin{array}{l}\text { If I regularly consult a good } \\
\text { doctor, I will lower the } \\
\text { probability of becoming ill }\end{array}$ & 1.00 & 6.00 & 3.1322 & 1.55061 \\
\hline $\begin{array}{l}\text { I can stay healthy merely by } \\
\text { consulting a doctor }\end{array}$ & 1.00 & 5.00 & 2.0743 & 1.28214 \\
\hline $\begin{array}{l}\text { It greatly depends on other } \\
\text { people (e.g. doctors, nurses, } \\
\text { relatives, friends) whether I stay } \\
\text { healthy or become ill }\end{array}$ & 1.00 & 6.00 & 3.0686 & 1.40438 \\
\hline Doctors keep me in good health & 1.00 & 6.00 & 2.8000 & 1.36878 \\
\hline $\begin{array}{l}\text { The care I get from others } \\
\text { determines how speedy my } \\
\text { recovery is }\end{array}$ & 1.00 & 6.00 & 3.7353 & 1.27118 \\
\hline $\begin{array}{l}\text { Exact following of doctor's } \\
\text { instructions is the best way of } \\
\text { maintaining good health }\end{array}$ & 1.00 & 6.00 & 3.4138 & 1.36048 \\
\hline
\end{tabular}

In the dimension of chance, the researched group found the following items most significant: "Even if I take care of myself, I can become ill easily" (3.66 points), "It seems that my state of health is affected by chance" (3.47 points) and "I often feel that if I am to become ill, I will, no matter what I do" (3.36 points). Tab.3.
Tab. 3. Dimension of chance according to the students.

\begin{tabular}{|l|c|c|c|c|}
\hline \multicolumn{1}{|c|}{ Chance } & Min. & Max. & Mean & $\begin{array}{c}\text { Standard } \\
\text { Deviation }\end{array}$ \\
\hline $\begin{array}{l}\text { I often feel that if I am to become } \\
\text { ill, I will, no matter what I do }\end{array}$ & 1.00 & 6.00 & 3.3600 & 1.64058 \\
\hline $\begin{array}{l}\text { It seems to me that my state of } \\
\text { health is affected by chance }\end{array}$ & 1.00 & 6.00 & 3.4798 & 1.55365 \\
\hline $\begin{array}{l}\text { When I become ill, I just must } \\
\text { wait until it goes away }\end{array}$ & 1.00 & 6.00 & 3.2629 & 1.49695 \\
\hline $\begin{array}{l}\text { When I am healthy, } \\
\text { I am just lucky }\end{array}$ & 1.00 & 6.00 & 3.1667 & 1.59871 \\
\hline $\begin{array}{l}\text { Even if I take care of myself, } \\
\text { I can become ill easily }\end{array}$ & 1.00 & 6.00 & 3.6667 & 1.38252 \\
\hline When I am ill, it is my fate & 1.00 & 6.00 & 3.0462 & 1.41756 \\
\hline
\end{tabular}

The dependencies calculated between social and demographic factors and dimensions of health locus of control (MHLC-B) indicated, that the group of oldest students aged 22 years old or more, attributed the highest ranking to the dimension of internal health control (26.05 points). The students living in rural areas also ascribed that dimension to a higher ranking (26.29 points) than the students from urban areas (25.30 points). Significant dependencies were not found between the age, place of residence and health locus of control ( $\mathrm{p}>0.05)$.

Taking into account courses of studies, the students of paramedics obtained the highest weight (27.10 points) in the dimension of internal control in comparison with the students of midwifery (25.87 points) and nursing (25.54 points). No statistically significant differences were noted among the particular groups ( $\mathrm{p}>0.05)$.

Statistically relevant differences were observed in the assessment of significance of the influence of others as a factor essential in health assessment. The greatest significance of the dimension was found in the respondents who were uncertain about their state of health in self-assessment (21.05 points) in comparison with the individuals who determined themselves as healthy or unhealthy ones $(\mathrm{p}<0.05)($ Tab. 4.).

Tab. 4. Dimensions of health locus of control dependent on health self-assessment of the respondents.

\begin{tabular}{|c|c|c|c|c|c|}
\hline \multirow{3}{*}{$\begin{array}{l}\text { Health locus of control } \\
\text { (dimension) }\end{array}$} & \multicolumn{3}{|c|}{$\begin{array}{l}\text { Do you think you are } \\
\text { a healthy person? }\end{array}$} & \multirow{3}{*}{$\mathrm{Chi}^{2}$} & \multirow{3}{*}{$\mathbf{p}$} \\
\hline & Yes & No & $\begin{array}{l}\text { I don't } \\
\text { know }\end{array}$ & & \\
\hline & \multicolumn{3}{|c|}{ Mean } & & \\
\hline Internal & 25.85 & 24.40 & 27.11 & 3.970 & 0.137 \\
\hline Influence of others & 17.98 & 17.07 & 21.05 & 6.306 & 0.043 \\
\hline Chance & 19.79 & 21.50 & 20.65 & 1.832 & 0.400 \\
\hline
\end{tabular}

The students could choose a range of items concerning health behaviours linked with taking care of one's own health. The vast majority of them (82.3\%) declared that they always fasten seat belts while travelling by car. Over half of the respondents (54.3\%) stated that they have a healthy diet, do sports (54.9\%) and take care of their appropriate weight (52\%). Almost every third person (38.9\%) admitted not taking harmful substances. 
The research revealed that females significantly more frequently do sport than males (77.1\% vs. $22.9 \%), \mathrm{p}=0.001$ and avoid harmful substances ( $99.6 \%$ vs. $4.4 \%)$. The students of nursing were found to avoid harmful substances (cigarettes, alcohol, illicit drugs, etc.) with statistically more significant frequency than the students of midwifery (38.2\%) and paramedics (5.9\%). It is statistically significant that the students of midwifery $(43.8 \%)$ do sport more frequently than the students of nursing $(37.5 \%)$ and paramedics (18.8\%).

\section{DISCUSSION}

The internal health locus of control is affected by numerous factors which are associated with the impact of family, peers, media, healthcare, health education, high self-efficacy and the position of health in the individual hierarchy of values $[11,12]$.

This study revealed that the students of health sciences attribute the highest ranking to the internal dimension of health control. The highest weight to that dimension is given by the students of paramedics, what may show that those students are more aware of responsibility for their own health and health of individuals with whom or for whom they work. It is worth mentioning that according to the Act on the National Emergency Medical Services of 2006 paramedics are obliged to provide help to every person in life-threatening condition [13]. The research of 230 students of the Medical University of Łódź conducted by Fiszer et al. [14] indicated that gender affects health locus of control. To a greater extent, men were more convinced of their control over their health than women, while women were characterised by stronger conviction of the influence of others, including some institutions on their health.

Norma and Bennet [15] think that the internal health locus of control makes the individuals who represent it more autonomous while taking some decisions and more responsible for their own health aspiring to maintaining or improving it. In the opinion of other authors, health education and the impact of different social factors on the cognitive and emotional sphere are of great significance in choosing pro-health behaviours and preserving health [16].
Further analysis of the data obtained showed that the students dwelling rural areas gave higher weight to the internal dimension of health locus than the students from the urban areas. The same observation was made by Piasecka et al. [17] in the research on medical students.

The students who could not determine whether they were healthy, significantly more frequently ascribed greater importance the influence of others dimension on their health than the students who considered themselves healthy. It is supposed to result from very young age of the individuals researched and their dependence on their parents, teachers or doctors in the case of their health decisions [13].

Cairns et al. [18] and Chubb et al. [19] noticed that the sense of health control changes in particular individuals with time and the older they are, the more internal it becomes.

The research presented showed that every second respondent declared to be on a healthy diet. The data obtained correspond with those in research on eating habits in students by Krajewska et al. [20], Rasińska [21], Misarz et al. [22] and Piasecka et al. [17]. Almost every third student admitted avoiding harmful substances such as cigarettes, alcohol or illicit drugs. Strzelecki et al. [23] indicated that students with internal health control show anti-health behaviours regarding drinking alcohol, taking drugs and smoking cigarettes to a lower degree than those with external health locus of control.

\section{CONCLUSIONS}

1. The group of students researched is characterised by internal health locus of control and the students of paramedics give the highest weight to that.

2. Health control in the dimension of the influence of others on health is significant in the group of students who were uncertain about their health status in self-assessment in comparison with the individuals defining themselves as healthy.

3. Positive health behaviours associated with taking care of own health are more frequently declared by females and students of nursing and midwifery than by students of paramedics.

\section{Umiejscowienie kontroli zdrowia a deklarowane zachowania zdrowotne studentów nauk o zdrowiu}

\section{WSTĘP}

Zdrowie jest wartością, dzięki której człowiek może realizować swoje aspiracje i potrzebę satysfakcji oraz zmieniać środowisko, w którym żyje [1]. Zdrowie uznaje się zazwyczaj za wstępny warunek pozwalający na zaspokojenie potrzeb życiowych. Jest także środkiem potrzebnym do osiągnięcia różnych życiowych celów. Do najważniejszych czynników warunkujących zdrowie należą zachowania zdrowotne, które składają się na styl życia człowieka [2, 3]. Zachowania zdrowotne można definiować jako zachowania, które w świetle współczesnej wiedzy medycznej wywołują określone, pozytywne lub negatywne skutki zdrowotne u osób, które je realizują [4]. Zachowania zdrowotne określa się również jako wszelkie zachowania, do których zalicza się nawyki, zwyczaje, postawy oraz przyjmowane wartości w odniesieniu do zdrowia [5]. 
Do zachowań zdrowotnych sprzyjających utrzymaniu zdrowia należą między innymi tj.: regularnie podejmowana aktywność fizyczna, odpowiednia dieta, właściwa ilość snu, rezygnacja ze stosowania używek, sposoby radzenia sobie ze stresem oraz zapinanie pasów bezpieczeństwa [6]. Zachowania zdrowotne kształtowane są od wczesnego dzieciństwa pod wpływem różnych czynników $\mathrm{w}$ domu, szkole czy grupie rówieśniczej. Stanowią one składowy element stylu życia, który oznacza charakterystyczny dla jednostki lub grupy sposób zachowania się [7]. Styl życia, będący wytworem kultury, jest z nią nierozerwalnie związany, gdyż to ona go kreuje. Styl życia odpowiada za ok. $60 \%$ potencjału zdrowotnego ludzi [8].

Studiowanie to niepowtarzalny czas w życiu młodego człowieka. W tym okresie młodzież podejmuje samodzielne próby i decyzje o stylu życia, jakimi będzie kierowała się w swojej codzienności. Na styl życia studentów składa się wiele czynników tj.: rozkład zajęć dydaktycznych, zmęczenie, lokalizacja uczelni względem miejsca zamieszkania oraz różne nawyki wyniesione $\mathrm{z}$ domu rodzinnego [9]. Znaczącą rolę w podejmowaniu zachowań zdrowotnych przez poszczególne jednostki w tym ludzi młodych, odgrywa umiejscowienie kontroli zdrowia. Poczucie kontroli nad zdrowiem cechuje się przekonaniem o tym, że ma się wpływ na własne zdrowie. Wewnętrzne umiejscowienie kontroli zdrowia przekłada się na zwiększoną odpowiedzialność za swoje zdrowie [10]. Przypisywanie wpływu na własne zdrowie innym osobom lub przypadkowi powoduje często, że nie odpowiada się samemu za własne zdrowie [3].

\section{CEL PRACY}

Celem niniejszej pracy jest określenie wybranych uwarunkowań kontroli zdrowia i zachowań zdrowotnych studentów nauk o zdrowiu.

\section{MATERIAŁ I METODYKA}

Badania przeprowadzono w kwietniu i maju 2016 roku wśród studentów 6 kierunków studiów (pielęgniarstwo, położnictwo, ratownictwo medyczne, fizjoterapia, dietetyka oraz zdrowie Publiczne) na Wydziale Nauk o Zdrowiu UM w Lublinie. Rozdano 250 kwestionariuszy ankiety. Zwrotnie uzyskano 175 prawidłowo wypełnionych (zwrotność na poziomie $70 \%$ ). Nie otrzymano zwrotnie wypełnionej żadnej ankiety z kierunków fizjoterapia, dietetyka oraz zdrowie publiczne.

Do zebrania materiału użyto kwestionariusza ankiety własnego autorstwa oraz standaryzowanej, Wielowymiarowej Skali Umiejscowienia Kontroli Zdrowia (MHLC - B), wg. Z. Juczyńskiego. Skala MHLC - B (The Multidimensional Health Locus of Control Scale), składa się z 18 stwierdzeń, które odnoszą się do trzech wymiarów kontroli zdrowia. Pierwszy wymiar - wewnętrzny (W) oznacza, że kontrola nad zdrowiem zależy od nas samych, drugi dotyczy wpływu innych osób (I), na nasze zdrowie, w tym pracowników służby zdrowia, trzeci odnosi się do wpływu przypadku (P) lub innych czynników zewnętrznych na nasz stan zdrowia. Rzetelność wersji B wynosi wg. wskaźnika alfa Cronbaha 0,64 dla kontroli wewnętrznej, 0,63 - dla przypadku i 0,59 - dla wpływu innych. Skala obejmuje 6 stopni oceny, poszczególnych stwierdzeń od: zdecydowanie nie zgadzam się (1 punkt) do zdecydowanie zgadzam się (6 punktów) [10].

Autorski kwestionariusz ankiety zawierał dane metryczkowe, tj.: wiek, płeć, miejsce zamieszkania, kierunek studiów oraz pytania o zachowania prozdrowotne i antyzdrowotne.

Badania przeprowadzono zgodnie z zasadami Deklaracji Helsińskiej. Każdy respondent zaproszony do udziału w badaniu został poinformowany o jego celu, zapewniony o całkowitej anonimowości przebiegu procesu badawczego i zgromadzonych danych oraz możliwości wycofania się z brania udziału w badaniu. Wartości analizowanych parametrów scharakteryzowano przy pomocy liczności i odsetka oraz wartości średniej i mediany. Dla zmiennych ciągłych do oceny różnic pomiędzy dwiema grupami zastosowano test U Manna -Whitneya, natomiast dla wielu grup Kruskala-Wallisa. Badania statystyczne przeprowadzono w oparciu o oprogramowanie komputerowe SPSS Statistics 12.0.

\section{Charakterystyka grupy badanej}

Kwestionariusz ankiety poprawnie wypełniło 175 (70\%) studentów z 3 kierunków: Pielęgniarstwa - 81 $(46,3 \%)$, Położnictwa - $72(41,1 \%)$ i Ratownictwa Medycznego 22 (12,6\%). Wśród badanych, kobiety stanowiły $85,7 \%(n=150)$, a mężczyźni $14,3 \%(n=25)$. Średni wiek ankietowanych wynosił 21,4 lat $(S D=3,6)$. Najmłodszy badany miał 19 lat, najstarszy 49 lat. Połowa respondentów (50,9\%), miała od 19 do 20 lat, 24\% miało 21 lat, zaś $25,1 \%$ badanych było w wieku 22 lata i powyżej. Ponad $(56,6 \%)$ studentów pochodziło ze wsi, zaś pozostałe $43,4 \%$ $\mathrm{z}$ miasta. Ponad $54,3 \%$ badanych mieszkało na stancji, $1 / 3$ $(33,1 \%)$ w domu rodzinnym, a $(12,6 \%)$ w akademiku.

\section{WYNIKI}

Ankietowani w największym stopniu, przypisywali znaczenie wewnętrznemu wymiarowi kontroli zdrowia, jako czynnikowi mającemu wpływ na zdrowie (Rycina 1).

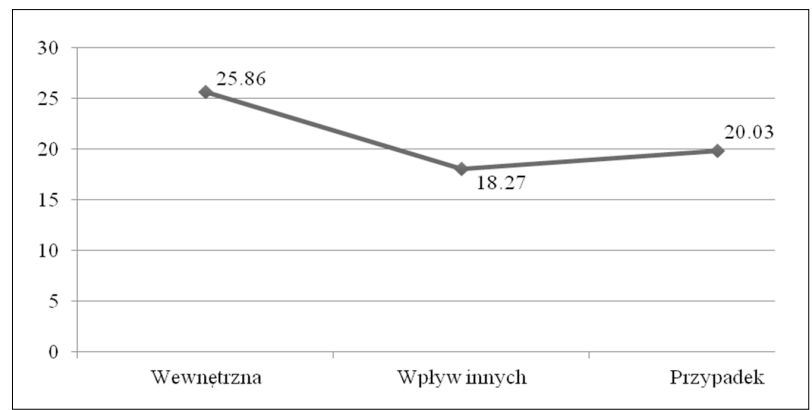

Ryc 1. Wymiary umiejscowienia kontroli zdrowia wg. opinii badanych studentów.

W wymiarze wewnętrznej kontroli zdrowia ankietowani najczęściej wskazywali na stwierdzenia: „ponoszę pełną odpowiedzialność za swoje zdrowie” (5,24 pkt.), „moje samopoczucie fizyczne zależy od tego, jak dobrze 
dbam o siebie” (4,75 pkt.) oraz „jeżeli zachoruję, to do zdrowia powracam o własnych siłach" (4,50 pkt.). Tabela 1.

Tab. 1. Wymiar wewnętrznej kontroli zdrowia w opinii studentów.

\begin{tabular}{|l|c|c|c|c|}
\hline \multicolumn{1}{|c|}{ Wewnętrzna kontrola } & Min. & Maks. & Średnia & $\begin{array}{c}\text { Odchylenie } \\
\text { standardowe }\end{array}$ \\
\hline $\begin{array}{l}\text { Jeżeli zachoruję, to do zdrowia } \\
\text { powracam o własnych siłach }\end{array}$ & 1,00 & 6,00 & 4,5029 & 1,21709 \\
\hline $\begin{array}{l}\text { Ponoszę pełną odpowiedzialność } \\
\text { za swoje zdrowie }\end{array}$ & 2,00 & 6,00 & 5,2428 & 1,94562 \\
\hline $\begin{array}{l}\text { Cokolwiek złego się dzieje } \\
\text { z moim zdrowiem, } \\
\text { to jest to moja wina }\end{array}$ & 1,00 & 6,00 & 3,1829 & 1,43067 \\
\hline $\begin{array}{l}\text { Moje samopoczucie fizyczne } \\
\text { zależy od tego, jak dobrze } \\
\text { dbam o siebie }\end{array}$ & 1,00 & 6,00 & 4,7529 & 1,13375 \\
\hline $\begin{array}{l}\text { Kiedy choruje, to wiem, że to } \\
\text { dlatego, iż o siebie nie zadbałem }\end{array}$ & 1,00 & 6,00 & 3,7701 & 1,34036 \\
\hline Kiedy choruję, jest to sprawa losu & 1,00 & 6,00 & 4,4128 & 1,16401 \\
\hline
\end{tabular}

W wymiarze związanym $\mathrm{z}$ wpływem innych studenci wybrali odpowiedzi: „opieka, którą otrzymuję od innych, decyduje o tym jak szybko powracam do zdrowia” $(3,73$ pkt.), „dokładne wypełnianie poleceń lekarza jest najlepszym sposobem zachowania dobrego zdrowia" (3,41 pkt.) oraz „jeżeli regularnie będę się konsultował z dobrym lekarzem, to zmniejszę prawdopodobieństwo zachorowania” (3,13 pkt.). Tabela 2 .

Tab. 2. Wymiar wpływu innych w opinii studentów.

\begin{tabular}{|l|c|c|c|c|}
\hline \multicolumn{1}{|c|}{ Wpływ innych } & Min. & Maks. & Średnia & $\begin{array}{c}\text { Odchylenie } \\
\text { standardowe }\end{array}$ \\
\hline $\begin{array}{l}\text { Jeżeli regularnie będę się } \\
\text { konsultował z dobrym } \\
\text { lekarzem, to zmniejszę } \\
\text { prawdopodobieństwo } \\
\text { zachorowania }\end{array}$ & 1,00 & 6,00 & 3,1322 & 1,55061 \\
\hline $\begin{array}{l}\text { Swoje zdrowie mogę zachować } \\
\text { jedynie konsultując się } \\
\text { zlekarzem }\end{array}$ & 1,00 & 5,00 & 2,0743 & 1,28214 \\
\hline $\begin{array}{l}\text { To, czy pozostanę zdrowy czy też } \\
\text { zachoruje, zależy w dużej mierze } \\
\text { od innych ludzi (np. lekarzy, } \\
\text { pielęgniarek, rodziny, przyjaciół) }\end{array}$ & 1,00 & 6,00 & 3,0686 & 1,40438 \\
\hline $\begin{array}{l}\text { Lekarze utrzymują mnie } \\
\text { w dobrym zdrowiu }\end{array}$ & 1,00 & 6,00 & 2,8000 & 1,36878 \\
\hline $\begin{array}{l}\text { Opieka, którą otrzymuję } \\
\text { od innych, decyduje o tym jak } \\
\text { szybko powracam do zdrowia }\end{array}$ & 1,00 & 6,00 & 3,7353 & 1,27118 \\
\hline $\begin{array}{l}\text { Dokładne wypełnianie poleceń } \\
\text { lekarza jest najlepszym } \\
\text { sposobem zachowania dobrego } \\
\text { zdrowia }\end{array}$ & 1,00 & 6,00 & 3,4138 & 1,36048 \\
\hline
\end{tabular}

W wymiarze związanym z przypadkiem dla badanych najistotniejsze były stwierdzenia: „nawet jeśli dbam o siebie, łatwo mogę zachorować” (3,66 pkt.), „wydaje mi się, że na mój stan zdrowia duży wpływ mają przypadkowe zdarzenia” (3,47 pkt.) oraz „często czuję, że jeżeli mam zachorować, to zachoruję niezależnie od tego co zrobię" (3,36 pkt.). Tabela 3.
Tab. 3. Wymiar przypadku w opinii studentów.

\begin{tabular}{|l|c|c|c|c|}
\hline \multicolumn{1}{|c|}{ Przypadek } & Min. & Maks. & Średnia & $\begin{array}{c}\text { Odchylenie } \\
\text { standardowe }\end{array}$ \\
\hline $\begin{array}{l}\text { Często czuję, że jeżeli mam } \\
\text { zachorować, to zachoruję } \\
\text { niezależnie od tego co zrobię }\end{array}$ & 1,00 & 6,00 & 3,3600 & 1,64058 \\
\hline $\begin{array}{l}\text { Wydaje mi się, że na mój stan } \\
\text { zdrowia duży wpływ mają } \\
\text { przypadkowe zdarzenia }\end{array}$ & 1,00 & 6,00 & 3,4798 & 1,55365 \\
\hline $\begin{array}{l}\text { Kiedy zachoruję, muszę po prostu } \\
\text { poczekać aż mi przejdzie }\end{array}$ & 1,00 & 6,00 & 3,2629 & 1,49695 \\
\hline $\begin{array}{l}\text { Kiedy jestem zdrowy, mam po } \\
\text { prostu szczęście }\end{array}$ & 1,00 & 6,00 & 3,1667 & 1,59871 \\
\hline $\begin{array}{l}\text { Nawet jeśli dbam o siebie, łatwo } \\
\text { mogę zachorować }\end{array}$ & 1,00 & 6,00 & 3,6667 & 1,38252 \\
\hline Kiedy choruję, jest to sprawa losu & 1,00 & 6,00 & 3,0462 & 1,41756 \\
\hline
\end{tabular}

Obliczone zależności między czynnikami społeczno-demograficznymi a wymiarami kontroli zdrowia (MHLC-B) wykazały, że osoby z najstarszej grupy wiekowej 22 lata i powyżej przypisywały najwyższą wagę wymiarowi wewnętrznej kontroli zdrowia (26,05 pkt.) niż ankietowani z młodszych grup wiekowych. Studenci pochodzący ze wsi nadawali temu wymiarowi również wyższą rangę $(26,29$ pkt.) niż osoby pochodzące $\mathrm{z}$ miasta $(25,30$ pkt.). Nie wykazano jednak istotnych zależności między wiekiem oraz miejscem pochodzenia a umiejscowieniem kontroli zdrowia ( $\mathrm{p}>0,05)$.

Biorąc pod uwagę kierunek studiów to studenci ratownictwa medycznego uzyskali najwyższą wagę (27,10 pkt.) $\mathrm{w}$ wymiarze kontroli wewnętrznej w porównaniu do studentów z położnictwa (25,87 pkt.) i pielęgniarstwa $(25,54$ pkt.). Nie stwierdzono jednak różnic istotnych statystycznie pomiędzy poszczególnymi grupami $(\mathrm{p}>0,05)$.

Zaobserwowano istotne statystycznie różnice w ocenie znaczenia wpływu innych, jako czynnika, który bierze się pod uwagę, przy ocenie stanu zdrowia. Największe znaczenie temu wymiarowi nadawali ankietowani, którzy w samoocenie nie byli pewni swojego stanu (21,05 pkt.), w porównaniu do osób, które określiły się jako zdrowe lub jako niezdrowe $(\mathrm{p}<0,05)$. Tabela 4 .

Tab. 4. Wymiary umiejscowienia kontroli zdrowia w zależności od samooceny stanu zdrowia badanych.

\begin{tabular}{|c|c|c|c|c|c|}
\hline \multirow{3}{*}{$\begin{array}{l}\text { Umiejscowienie kontroli } \\
\text { zdrowia (wymiar) }\end{array}$} & \multicolumn{3}{|c|}{$\begin{array}{c}\text { Czy uważa się Pan/Pani } \\
\text { za osobę zdrową? }\end{array}$} & \multirow{3}{*}{$\mathrm{Chi}^{2}$} & \multirow{3}{*}{$\mathbf{p}$} \\
\hline & Tak & Nie & $\begin{array}{c}\text { Nie } \\
\text { wiem }\end{array}$ & & \\
\hline & \multicolumn{3}{|c|}{ Średnia } & & \\
\hline Wewnętrzna & 25.85 & 24.40 & 27.11 & 3.970 & 0.137 \\
\hline Wpływ innych & 17.98 & 17.07 & 21.05 & 6.306 & 0.043 \\
\hline Przypadek & 19.79 & 21.50 & 20.65 & 1.832 & 0.400 \\
\hline
\end{tabular}

Studenci w pytaniu o zachowania zdrowotne związane z dbaniem o zdrowie mieli do wyboru szereg stwierdzeń. Zdecydowana większość (82,3\%) deklarowała, że zawsze zapina pasy bezpieczeństwa podczas podróży autem. Ponad (54,3\%), badanych stwierdziło, że odżywia się zdrowo, uprawia sport $(54,9 \%)$ oraz dba o prawidłową masę ciała (52\%). Blisko co trzecia osoba $(38,9 \%)$, podała, że rezygnuje $z$ używek. 
W badaniach wykazano, że kobiety istotnie częściej niż mężczyźni ( $\mathrm{p}=0,006)$ uprawiają sport $(77,1 \%$ vs. $22,9 \%)$, $\mathrm{p}=0,001$ oraz rezygnują $\mathrm{z}$ używek ( $99,6 \%$ vs. $4,4 \%)$, Stwierdzono, także, że studenci pielęgniarstwa (55,9\%) istotnie statystycznie $(\mathrm{p}=0,04)$ częściej rezygnują z używek (papierosy, alkohol, narkotyki, itp.) niż badani z dwóch pozostałych kierunków (położnictwo - 38,2\%; ratownictwo medyczne $-5,9 \%)$. Natomiast studenci z położnictwa $(43,8 \%)$, istotnie statystycznie $(\mathrm{p}=0,006)$ częściej uprawiają sport niż studenci pielęgniarstwa $(37,5 \%)$ i ratownictwa medycznego (18,8\%).

\section{DYSKUSJA}

Na wewnętrzne umiejscowienie kontroli zdrowia mają wpływ różne czynniki, które wiążą się z oddziaływaniem środowiska rodzinnego, rówieśniczego, mediów, ochrony zdrowia, edukacji zdrowotnej, a także wysokiego poczucia własnej skuteczności oraz pozycji zdrowia, jakie zajmuje ono w osobistej hierarchii wartości $[11,12]$

Przeprowadzone badania wykazały, że studenci nauk o zdrowiu z trzech badanych kierunków najwyższą rangę, przypisują wewnętrznemu wymiarowi kontroli zdrowia. Najwyższą wagę nadają temu wymiarowi w odniesieniu do pozostałych ankietowanych, studenci ratownictwa medycznego. Uzyskany wynik może wskazywać na to, że studenci tego kierunku czują większą odpowiedzialność za zdrowie własne oraz osób z którymi pracują. Należy zauważyć, że zgodnie z Ustawą o Państwowym Ratownictwie Medycznym z 2006 roku, ratownicy medyczni należą do grupy zawodowej, która ma za zadanie zapewnić pomoc każdej osobie, która znajduje się w stanie nagłego zagrożenia życia [13]. Badania przeprowadzone przez Fiszera i wsp.[14] w grupie 230 studentów Uniwersytetu Medycznego w Łodzi pokazały, że płeć wpływa na umiejscowienie kontroli zdrowia. Mężczyźni w większym stopniu niż kobiety byli przekonani, że mogą kontrolować własne zdrowie, natomiast kobiety charakteryzowały się silniejszym przekonaniem o wpływie innych osób oraz instytucji na swój stan zdrowia.

Norma i Bennet [15], stwierdzili, że wewnętrzne umiejscowienie kontroli zdrowia sprawia, że osoby, które je prezentują są bardziej autonomiczne w podejmowaniu decyzji, posiadają duże poczucie odpowiedzialności za własne zdrowie oraz dążą do jego utrzymania i poprawy. W opinii innych autorów duże znaczenie w podejmowaniu zachowań prozdrowotnych i utrzymaniu zdrowia odgrywa edukacja zdrowotna oraz oddziaływanie różnych czynników społecznych na sferę poznawczą i emocjonalną [16].

Dalsza analiza uzyskanych badań wykazała, że studenci zamieszkujący tereny wiejskie nadawali wyższą wagę wewnętrznemu wymiarowi kontroli zdrowia niż osoby mieszkające w miastach. Tę samą zależność zaobserwowała, Piasecka i wsp.[17], prowadząc badania w grupie studentów medycyny.

Stwierdzono także, że studenci, którzy nie potrafili określić, czy są osobami zdrowymi istotnie częściej przypisywali większe znaczenie wymiarowi wpływu innych na swoje zdrowie, niż osoby, które uważały się za zdrowe.
Należy przypuszczać, że przyczyną takich wyników może być młody wiek badanych oraz to, że w znacznym stopniu uzależniają oni swoje decyzje dotyczące zdrowia od opinii znaczących dla nich osób tj: rodzice, nauczyciele czy lekarze [13].

Cairns i wsp. [18] oraz Chubb i wsp. [19] zaobserwowali, że poczucie kontroli zdrowia zmienia się u poszczególnych jednostek $\mathrm{z}$ upływem czasu, a wraz $\mathrm{z}$ wiekiem staje się bardziej wewnętrzne.

Prezentowane badania pokazały, że co drugi ankietowany deklarował, że zdrowo się odżywia. Uzyskane wyniki korespondują z badaniami Krajewskiej i wsp.[20], Rasińskej [21], Misarz i wsp. 2013 [22] oraz Piaseckiej i wsp. 2014 [17], które były także prowadzone w grupie studentów nt. oceny nawyków żywieniowych. Blisko co trzeci student podał, że rezygnuje $z$ używek tj. papierosy, alkohol czy narkotyki. Strzelecki i wsp. [23] w swoich badaniach wykazali, że uczniowie $\mathrm{z}$ wewnętrznym poczuciem kontroli zdrowia w mniejszym stopniu prezentują zachowania antyzdrowotne dotyczące nadużywania alkoholu, narkotyków i palenia papierosów w stosunku do osób z zewnętrznym umiejscowieniem kontroli zdrowia.

\section{WNIOSKI}

1. W badanej grupie studentów dominuje wewnętrzne umiejscowienie kontroli zdrowia, któremu najwyższą wagę przypisują studenci ratownictwa medycznego.

2. Kontrola zdrowia w wymiarze „wpływ innych osób” na zdrowie jest istotna w grupie studentów, którzy w samoocenie nie są pewni swojego stanu zdrowia w porównaniu do osób określających się jako zdrowe.

3. Pozytywne zachowania zdrowotne związane $z$ dbaniem o zdrowie deklarują częściej kobiety, studenci pielęgniarstwa i położnictwa, niż studenci ratownictwa medycznego.

\section{PIŚMIENNICTWO/REFERENCES}

1. Płotka A. Zdrowy styl życia psychicznego. Lublin: Wyd. NeuroCentrum; 2003.

2. Romanowska-Tołłoczko A. Styl życia studentów oceniany w kontekście zachowań zdrowotnych. Hygeia Public Heath. 2011;46 (1): 89-93.

3. Smoleń E, Cipora E, Penar-Zadarko B, Gazdowicz L. Wybrane zachowania zdrowotne młodzieży akademickiej a umiejscowienie kontroli zdrowia. Przegląd Medyczny Uniwersytetu Rzeszowskiego i Narodowego Instytutu Leków w Warszawie. Rzeszów. 2012; 4: 474-484.

4. Wojnarowska B. Edukacja zdrowotna. Warszawa: Wyd. Naukowe PWN; 2008.

5. Żołnierczuk-Kieliszek D. Zachowania zdrowotne i ich związek ze zdrowiem. [w:] T. Kulik, A. Pacian red. Zdrowie publiczne. Warszawa: PZWL; 2014, s. 64 -74.

6. Wardle J, Steptoe A. The European health and Behaviour Survey: rationale, methods and initial results from the United Kingdom. Soc Sci Med. 1991;33 (8): 925-936.

7. Tobiasz-Adamczyk B. Wybrane elementy socjologii zdrowia i choroby. Kraków: Wyd. Uniwersytetu Jagiellońskiego; 2000.

8. Zarzeczna-Baran M, Wojdak-Haasa E. Wiedza studentów akademii medycznej w Gdańsku o niektórych elementach stylu życia. Probl Hig Epidemiol. 2007;88 (1): 55-59.

9. Sochocka L, Wojtyłko A. Aktywność fizyczna studentów studiów stacjonarnych kierunków medycznych i niemedycznych. Medycyna Środowiskowa - Environmental Medicine. 2013;16 (2): 53-58.

10. Juczyński Z. Narzędzia pomiaru w promocji i psychologii zdrowia. Warszawa: PTP; 2001.

11. Bandura A. Heath Promotion by Social-Cognitive Means. Health Educ Behav. 2004; 31:143-161. 
12. Kościelak R. Poczucie umiejscowienia kontroli i przekonania o własnej skuteczności w zdrowiu i chorobie. Kraków: Impuls; 2010.

13. Ustawa z dnia 8 września 2006 r o Państwowym Ratownictwie Medycznym, rozdz.1, art. 1.

14. Fiszer K, Sobów T. Związek umiejscowienia kontroli zdrowia z depresyjnością wśród studentów uczelni medycznej. Medycyna Ogólna i Nauki o Zdrowiu. 2013; 3: 294299.

15. Norma P, Bennet P. Heath locus of control. [in:] Conner M, Norman P, ed. Predicting health behaviour. Buckingham: Open University Press.1996: 62-94.

16. Schwarzer R. Social-cognitive factors in changing health-related behaviour. Curr Dir in Psychol Sci. 2001; 10: 47-51.

17. Piasecka H, Nowicki G, Ślusarska B. Sposób żywienia i umiejscowienie kontroli zdrowia w grupie studentów medycyny. Piel XXI w. 2014;2 (47): 17-21.

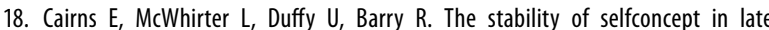
adolescence; Gender and situational effects. Pers Individual differences. 1990; 11: 937-944.

19. Chubb NH, Fertman Cl, Ross JL. Adolescent slef-esteem and locus of control: A logitudinal study of gender and age differences. Adolescence. 1997;32 (125): 113 129

20. Krajweska A, Słowiek-Gabryelska A. Ocena jakości żywienia studentów pierwszego roku zdrowia publicznego US. Zesz Nauk U Szczec. Prace Instytutu Kultury Fizycznej. 2008; 25:5-13.

21. Rasińska R. Nawyki żywieniowe studentów w zależności od płci. Now Lek. 2012; 81(4):354-359.

22. Misiarz M, Malczyk E, Żłoteńska-Synowiec M, Rydelek J i wsp. Ocena zachowań żywieniowych studentów kierunków medycznych i niemedycznych z województwa świętokrzyskiego. Piel Zdr Pub. 2013; 3(3): 272-365.

23. Strzelecki W, Cybulski M, Strzelecka M. Rola poczucia umiejscowienia kontroli w kształtowaniu wybranych zachowań zdrowotnych adolescentów. Now Lek. 2009; 78(1): 18-22.
Praca przyjęta do druku/Manuscript received: 23.01.2018

Praca zaakceptowana do druku/Manuscript accepted: 23.02.2018

Tłumaczenie/Translation: Katarzyna Szczekala 